\title{
Biogenic Synthesis of Gold Nanoparticles by Bacteria and Utilization of the Chemical Fabricated for Diagnostic Performance of Viral Hepatitis C Virus-NS4
}

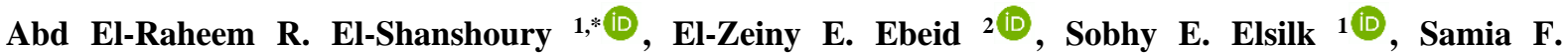 \\ Mohamed ${ }^{3}$, Mohamed E. Ebeid ${ }^{1}$ \\ 1 Bacteriology Unit, Microbiology Section, Botany and Microbiology Department, Faculty of Science, Tanta University, \\ Tanta 31527, Egypt \\ 2 Chemistry Department, Faculty of Science, Tanta University, Tanta 31527, Egypt \\ 3 Pharmacology and Toxicology Unit, Department of Biochemistry, Animal Health Institute, Giza, Egypt \\ * Correspondence: abrabsh@gmail.com;
}

Scopus Author ID 6602987135

Received: 5.06.2020; Revised: 30.06.2020; Accepted: 2.07.2020; Published: 7.07.2020

\begin{abstract}
Extracellular biosynthesis of gold nanoparticles (AuNPs) becomes a significant approach to NPs preparation. Development in medical diagnostics focuses on the nanomaterials, particularly AuNPs. This study focuses on the biogenic synthesis of AuNPs and, additionally, the use of the chemicals made-up in medical detection of hepatitis C Virus-NS4 (HCV-NS4). Cell-free extracts (CFE's) and cell biomass (CBM) of E. coli ATCC 8739, B. subtilis ATCC 6633, St. thermophilus ESH1 and $L$. acidophilus DSMZ 20079T mixed with Tetrachloroauric acid $\left(\mathrm{HAuC}_{14}\right)$ at 1:1(v/v) ratio, kept at distinctive temperatures and $\mathrm{pHs}$ for time intervals, and observed for AuNPs biogenesis. The chemically made-up AuNPs, 5'- hexanethiol, and the critical 20-base target oligonucleotide mixed. Single-stranded DNA (ssDNA) adsorbate on citrate-coated AuNPs used for the detection of the HCV-NS4 target oligonucleotide sequence. This study has advanced fast biogenic synthesis of stable AuNPs from $10^{-3} \mathrm{M}$ $\mathrm{HAuC}_{14}$ utilizing the bacteria mentioned above at $37^{\circ} \mathrm{C}, \mathrm{pH} 7$, and within fifteen minutes. UV spectrum at $520 \mathrm{~nm}, \mathrm{XRD}$, and TEM assured the development of AuNPs. Incorporated created up AuNPs recorded broad uptake bands and obtained the color modification from crimson to blue. The results directed to the biogenic synthesis of AuNPs and the attainable utilization of made-up AuNPs to seek out HCV-NS4.
\end{abstract}

Keywords: Gold nanoparticles; HCV-NS4; oligonucleotide; ssDNA; UV-spectra; XRD.

(c) 2020 by the authors. This article is an open-access article distributed under the terms and conditions of the Creative Commons Attribution (CC BY) license (https://creativecommons.org/licenses/by/4.0/).

\section{Introduction}

The field of nanotechnology gained attention in the recent past due to a wide spectrum of applications from biosorption and catalysis, therapeutics, rescue system, factory, farms, consumer goods, cosmetics, bioremediation, and biosensors design to diagnostics and medicinal applications [1-8]. Physical and chemical methods used for the synthesis of nanomaterials are often toxic and flammable [9], need extreme conditions, and environmental toxic or biological hazards reducing agents that are too harsh and non-ecofriendly. Alternatively, biological approaches using microorganisms and plant extracts for metal nanoparticles synthesis suggested as valuable options to traditional methods [10-14] and bionanofactories [15]. Attention paid to the biosynthesis of nanomaterials using bacteria [1619]. The exposure of Bacillus subtilis treated with gold chloride resulted in the synthesis of 
gold nanoparticles (AuNPs); however, Beveridge et al. [20] demonstrated that gold particles of nanoscale dimensions readily precipitated within bacterial cells by incubation of the cells with $\mathrm{Au}^{3+}$ ions. Biosynthesis of AuNPs has been carried out using Rhodopseudomonas capsulate [21-23], Bacillus subtilis [24], and actinomycetes [14,25]. An extracellular biosynthesis using cell supernatant of the bacteria Pseudomonas aeruginosa [26], the thermophilic bacterium Geobacterium stearothermophilus [27], a Gram-negative bacterium $P$. fluorescence [28] and Klebsiella pneumonia [29] have also been described. Although the mechanism for the reduction of AuNPs in the bacterium is still not well understood, earlier reports claimed that an enzyme belonging to the NADH reductase family was involved [3032]. The fight of certain capping proteins secreted by the bacterium G. stearothermophilus in the organization and stability of AuNPs was confirmed [27].

Infectious diseases are still a serious health care problem. Despite advancements in pathogen identification, some of the gold-standard diagnostic methods have limitations. Innovative, sensitive, specific, robust, and fast approaches to diagnosis are urgently required. In this connection, nanotechnology introduces a great chance to produce quick, correct, and cost-effective diagnostics to detect the pathogenic infectious agents $[2,3,10,33,34]$. The highly specific recognition properties of biomolecules combined with the unique visual properties of the inorganic nanoparticles make these composite materials attractive for use in the fields of diagnostics (non-photo bleaching immunolabels), sensitive probes for polynucleotide detection [35,36] and nanotechnologies [37]. The absorption of gold ions played a significant function in shaping and stabilizing the frame of gold nanocrystals [24,38]. AuNPs sow unique optical, thermal, chemical, physical, and electronic properties, derived from their size and composition $[39,40]$. AuNPs of absorption at $520 \mathrm{~nm}$ appears red when suspended in solution. Upon aggregation, their absorption occurs at $740 \mathrm{~nm}$, and the color changed from pink to blue due to the surface Plasmon of AuNPs. This change from crimson to blue color provides an answer to the comportment of a specific DNA target. When coupled to affinity legends, these AuNPs, when conjugated with specific oligonucleotides, can sense complementary DNA strands that detected by color changes [40,41]. Using AuNPs and their plasmonic shifts, the detection of nucleic acids of the pathogens attained [41], even in complex media like blood [42].

Complete eighty-five percent of the world 's nearly 170 million infected viral hepatitis (HCV) viruses are present in parts of Africa, Southeast Asia, and Middle Eastern nations. It is infecting an estimated 500,000 Egyptian annually. In particular, genotype $4 \mathrm{HCV}$ is very prevalent in Egypt, with $19 \%$ of the population infected. Despite this, frightening work administered characterizing the diversity of the genotype 4 sequence, which can be important to develop effective antiviral vaccines and therapies to address this genotype [43]. Egyptian population has an illness from the $\mathrm{HCV}$, particularly strains 4 that is way common in Egypt are increasing. Central to combating this deadly malady, economic diagnostic tools capable of widespread population screening devised. They applied nanotechnology as some way to detect viral RNA in a blood sample directly and concluded if the color remains red, the virus is not present. If it shifts to blue, the sample is positive for HCV infection [44]. Another survey [45] detected HCV-NS4 antigen in patients with chronic hepatitis C exploitation ELISA assay. They concluded that the detection of antigens by ELISA is a true check to confirm HCV infection. Recently, Draz and Shafiee [46] reviewed the developed applications of AuNPs in virus detection in terms of sensitivity, and detection varies, and time.

Since diagnosis is is that the primary strategy of virus management and elimination, and looking forward to the traits of a made-up AuNPs, this study aimed to develop the biogenic 
synthesis of AuNPs by means that of bacteriologic systems and application of the made-up AuNPs in clinical detection and diagnosing of HCV genotype four.

\section{Materials and Methods}

\subsection{Microorganisms and media.}

Escherichia coli ATCC 8739, Bacillus subtilus ATCC 6633 and DSMZ 20079 T for Lactobacillus acidophilus from our culture collection (Bacteriology Unit at Botany Department, Faculty of Science, Tanta University). Both E. coli and B. subtilus cultivated in Luria and Bertani (LB) broth containing (per liter): 10.0 g Tryptone; $5.0 \mathrm{~g}$ yeast extract, and 10.0 g sodium chloride [47]. Streptococcus thermophilus ESH1 isolated from yogurt. Both $L$. acidophilus and St. thermophilus cultivated in ST broth containing (per liter): $10.0 \mathrm{~g}$ casein enzymes hydrolyzate; $5.0 \mathrm{~g}$ yeast extract; $10.0 \mathrm{~g}$ sucrose, and $2.0 \mathrm{~g}$ dipotassium hydrogen phosphate [48].

\subsection{Biogenic synthesis of AuNPs from bacteria.}

Luria and Burrous and ST broths prepared, sterilized, and inoculated with freshly grown inoculums (18 h) of the test strains E. coli ATCC 8739, B. subtilis ATCC 6633, St. thermophilus ESH1 and L. acidophilus DSMZ 20079T $\left(1 \times 10^{5}\right) \mathrm{cfu} / \mathrm{ml}$. Growth was performed in $250 \mathrm{ml}$ Erlenmeyer flasks containing $100 \mathrm{ml}$ growth medium. The culture flasks incubated for $24 \mathrm{~h}$ at $35^{\circ} \mathrm{C}$, and then the cells were separated from the culture by centrifugation at 1360 $\mathrm{xg}$ for $20 \mathrm{~min}$. The resultant pellets were used as wet cell biomass (CBM) for further experiments. Other pellets were resuspended in deionized water for 24 hours, centrifuged at $1360 \mathrm{xg}$ for $20 \mathrm{~min}$, and the clear supernatants used as cell-free extracts (CFE's) for further experiments. Different concentrations of tetrachloroauric acid $\left(\mathrm{HAuC}_{14}\right)$ were added to the $\mathrm{CFE}$ or the suspended wet CBM of each bacterium in a 1:1 (v/v) ratio. Mixtures were kept at different temperatures $25,30,35,40$, and $45^{\circ} \mathrm{C}$ and $\mathrm{pH} 7$ for different time intervals, and observed for nanomaterial formation and color change. Change in color from light yellow to pink color is characteristic of AuNPs formation in the solutions.

\subsection{Chemical preparation of AuNPs.}

Rounded approximately $13 \mathrm{~nm}$ diameter AuNPs prepared by the citrate reduction of $\mathrm{HAuC}_{14} .3 \mathrm{H}_{2} \mathrm{O}$ [51]. An aqueous solution of $\mathrm{HAuC}_{14} .3 \mathrm{H}_{2} \mathrm{O}(1 \mathrm{mM}, 100 \mathrm{ml})$ brought to reflux while stirring. Then $10 \mathrm{ml}$ of $1 \%$ trisodium citrate solution (as nucleating and reducing agent) added quickly, which resulted in a change in solution color from pale yellow to deep red. After the color change, the solution was refluxed for an extra $15 \mathrm{~min}$, allowed to cool to room temperature. A typical solution of $13 \mathrm{~nm}$ diameter AuNPs exhibited a characteristic surface plasmon band centered at 518-520 $\mathrm{nm}$ [49].

\subsection{UV-visible and fluorescence spectroscopy.}

The formation of AuNPs characterized by UV-visible spectroscopy using a Shimadzu UV-160A Spectro-photometer used at a resolution of $1 \mathrm{~nm}$. Steady-state emission spectra measured using a Shimadzu RF 510 spectrofluorophotometer and the fluorescence spectra of nanoparticles analysis carried out as illustrated [50,51]. 


\subsection{Transmission electron microscopy (TEM).}

The AuNPs formed by the CFE's and CBM of the test bacteria imaged using TEM; Joel, 100SX, Japan with AMT digital camera. Each specimen separated ultrasonically, and one or two drops of the suspension deposited onto holy-carbon coated TEM copper grids and dried using an infrared lamp before taking photography.

\subsection{X-ray diffraction analysis.}

The formation of AuNPs checked by XRD technique using an X-ray diffractometer (Phillips PW 1729/40 generator, diffractometer, one line reactor) with $\mathrm{Cu} K \alpha$ radiation $\lambda=$ $1.5405 \AA$ over a wide range of Bragg angles $\left(20\right.$ to $80^{\circ}$ ). Glass slides coated with of AuNPs tested. For more efficient XRD studies, slides were primarily coated with silica gel and then loaded with AuNPs solution before drying.

\subsection{Target oligonucleotide detection procedure.}

The nanoparticle-based detection protocol applied here with two different probes that would align in a head-to-tail fashion to the complementary 20-base target oligonucleotide (Fig.1). The lyophilized target oligonucleotide was suspended in $1 \mathrm{ml}$ of a stock $0.1 \mathrm{M} \mathrm{NaCl}$, $10 \mathrm{mM}$ phosphate buffer, $\mathrm{pH}$ 7. In clean and sterilized Eppendorf tubes, take $0.2 \mathrm{ml}$ AuNPs of stock suspension in separate Eppendorf tubes, from each probe 1 and 2, mix $0.2 \mathrm{ml}$ with 0.2 $\mathrm{ml}$ of the stock solution. Allow the mixture to stand for $16 \mathrm{~h}$ after first shaking.

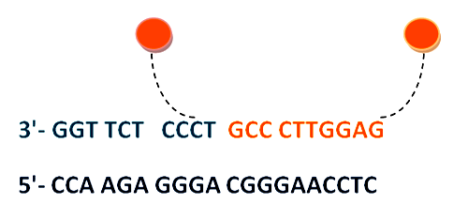

Figure 1. Alkanethiol probe oligonucleotide-modified $13 \mathrm{~nm}$ diameter Au nanoparticles (probes 1 and 2) and target oligonucleotides (3) used for colorimetric detection. Dashed lines represent hexanethiol, HS-(CH2)6 groups of the mercapto alkyl oligonucleotide strands bound to the nanoparticles.

\subsection{Colorimetric detection of HCV genotype 4.}

A target oligonucleotide of high CG ratio selected in this experiment which is a part of the genome sequence in HCV genotype 4 according to Genome Data Base. The selected target oligonucleotide sequence was (5'-CCA AGA GGG A CGGGA ACC TC-3'). Two complementary probes synthesized and linked to hexane thiols as follows: Probe 1: 3'-GGT TCT CCC T (CH2)6-HS 5' and Probe 2: 3'-GCC CTT GGA G (CH2)6-HS 5'). Oligonucleotides and probes purchased from Sigma in a lyophilized form of the following amounts: Probe 1 Code 000040: 5'-[HS-C6]- TCCCTCTTGG-3' ( $21.8 \mathrm{nmol}$ ) and Probe 2 Code 000050: 5' -[HS-C6]-GAGGTTCCCG-3' (373.4 nmol), and Target oligonucleotide Code 000060: 5'-CCAAGAGGGACGGGAACCTC-3' (35.5 nmol). An aqueous solution of HAuC 14 $(1 \mathrm{mM}, 500 \mathrm{ml})$ refluxed during stirring, and then $50 \mathrm{ml}$ of $38.8 \mathrm{mM}$ trisodium citrate solution added quickly. Accordingly, the pale yellow color has changed to a deep red. After the color change, the solution was refluxed for the other $15 \mathrm{~min}$ and then allowed to cool to room temperature. A solution of absorbance: $\mathrm{A}=2.5$ absorbance units applied as a decent answer. 
2.9. Loading of gold nanoparticles modified with 5'-alkanethiol probes and spectrophotometric detection.

AuNPs of $\approx 13$ diameters were chemically modified with 5'- hexanethiol probes in two separate experiments. The UV-vis spectra of solutions measured using a quartz cuvette of 2 $\mathrm{mm}$ path length and the solutions used without further dilution. The target oligonucleotide was detected using probe-loaded gold nanoparticles (Alkanethiol probe oligonucleotide-modified $13 \mathrm{~mm}$ diameter AuNPs probes 1 and 2, and target oligonucleotides 3). The nanoparticle-based applied two different investigations that would adjust in a head-to-tail fashion to the complementary 20-base target oligonucleotide used for colorimetric detection. Dashed lines represent hexanethiol, HS-(CH2)6 groups of the mercapto alkyl oligonucleotide strands bound to the nanoparticles. Eppendorf tubes containing the mixture of both two solutions were frozen in liquid nitrogen for $5 \mathrm{~min}$ and then it was dissolved at room temperature. The absorption spectrum measured against a buffer solution as a blank using a $0.1 \mathrm{~mm}$ path length cuvette.

\section{Results and Discussion}

Cell-free extract (CFE's) of the four bacteria Escherichia coli ATCC 8739, Bacillus subtilus ATCC 6633, Lactobacillus acidophilus DSMZ 20079T and Streptococcus thermophilus added to different concentations of $\mathrm{HAuC}_{14}$ solutions $10^{-1}-10^{-5} \mathrm{M}$ in $1: 1(\mathrm{v} / \mathrm{v})$ ratio at $37^{\circ} \mathrm{C}$ and $\mathrm{pH}$ 7. The highest absorbance observed at $520 \mathrm{~nm}$ (Table 1), corresponds to the concentration $10^{-3} \mathrm{M} \mathrm{HAuC}_{14}$.

Table 1. Development of the color formation of AuNPs measured at $520 \mathrm{~nm}$, using different concentrations of $\mathrm{M} \mathrm{HAuC}_{14}$ and the cell-free extracts (CFE's) of tested bacteria (1/1, v/v) at $37^{\circ} \mathrm{C}, \mathrm{pH} 7$, and after $15 \mathrm{~min}$.

\begin{tabular}{l|l|l|l|l|l}
\multirow{2}{*}{ CFE's } & \multicolumn{5}{|c}{ Concentrations of $\mathbf{H A C l}_{\mathbf{4}}(\mathbf{M})$ / Absorbances } \\
\cline { 2 - 7 } & $\mathbf{1 0 - 1}$ & $\mathbf{1 0 - 2}$ & $\mathbf{1 0 - 3}$ & $\mathbf{1 0 - 4}$ & $\mathbf{1 0 - 5}$ \\
\hline E. coli & precipitation & precipitation & 0.16 & 0.10 & 0.06 \\
\hline B. subtilis & precipitation & precipitation & 0.02 & 0 & 0 \\
\hline St. thermophilus & precipitation & precipitation & 0.21 & 0.14 & 0.05 \\
\hline L. acidophilus & precipitation & 0.02 & 0.11 & 0.0 & 0.0
\end{tabular}

The biosynthesis efficiency of gold nanoparticles (AuNPs) differed according to the temperature used (Table 2) and the nature of enzyme either from CFE's or CBM. It increased with increasing temperature until an optimum temperature in the range $35-37^{\circ} \mathrm{C}$. A decrease in biosynthesis efficiency occurs at ca. $45^{\circ} \mathrm{C}$ due to enzyme deactivation at high temperatures. $\mathrm{HAuC}_{14}$ gives precipitate in alkaline medium prohibiting $\mathrm{pH}$ studies in alkaline media. Thus, AuNPs were prepared from the aqueous solution of $\mathrm{HAuC}_{14}$ in their respective acidic solutions.

Table 2. Absorbance at $520 \mathrm{~nm}$ of the biosynthesized gold nanoparticles using $10^{-3} \mathrm{M} \mathrm{HAuC}_{14}$ by the tested bacteria at different temperatures, $\mathrm{pH} 7$, and after $15 \mathrm{~min}$.

\begin{tabular}{|c|c|c|c|c|c|c|}
\hline \multirow[b]{2}{*}{ Sample } & & \multicolumn{5}{|c|}{ Temperatures $\left({ }^{\circ} \mathrm{C}\right) /$ Absorbances } \\
\hline & & 25 & 30 & 35 & 37 & 45 \\
\hline \multirow[b]{2}{*}{ E. coli } & CFE & 0.02 & 0.07 & 0.1 & 0.15 & ND \\
\hline & $\overline{\mathrm{CBM}}$ & ND & 0.08 & 0.11 & 0.18 & ND \\
\hline \multirow{3}{*}{ B. subtilis } & CFE & ND & ND & ND & ND & ND \\
\hline & CBM & 0.04 & 0.09 & 0.11 & 0.19 & ND \\
\hline & CFE & 0.07 & 0.11 & 0.12 & 0.22 & ND \\
\hline \multirow[t]{2}{*}{ St. thermophilus } & CBM & 0.12 & 0.5 & 0.2 & 0.23 & 0.02 \\
\hline & CFE & 0.02 & 0.06 & 0.08 & 0.12 & ND \\
\hline L. acidophilus & $\overline{\mathrm{CBM}}$ & 0.01 & 0.03 & 0.2 & 0.24 & ND \\
\hline
\end{tabular}

$\mathrm{ND}=$ Not detected under the experimental conditions; $\mathrm{CEF}=\mathrm{Cell}$ free extract; $\mathrm{CBM}=\mathrm{Cell}$ biomas 
CFE's of the before four bacteria added to $10^{-3} \mathrm{M}$ in $1: 1(\mathrm{v} / \mathrm{v})$ ratio at $37^{\circ} \mathrm{C}$ and $\mathrm{pH} 7$. After around $15 \mathrm{~min}$, AuNPs formation observed, and a color change from pale yellow to pink coloration occurred (Figure 2).

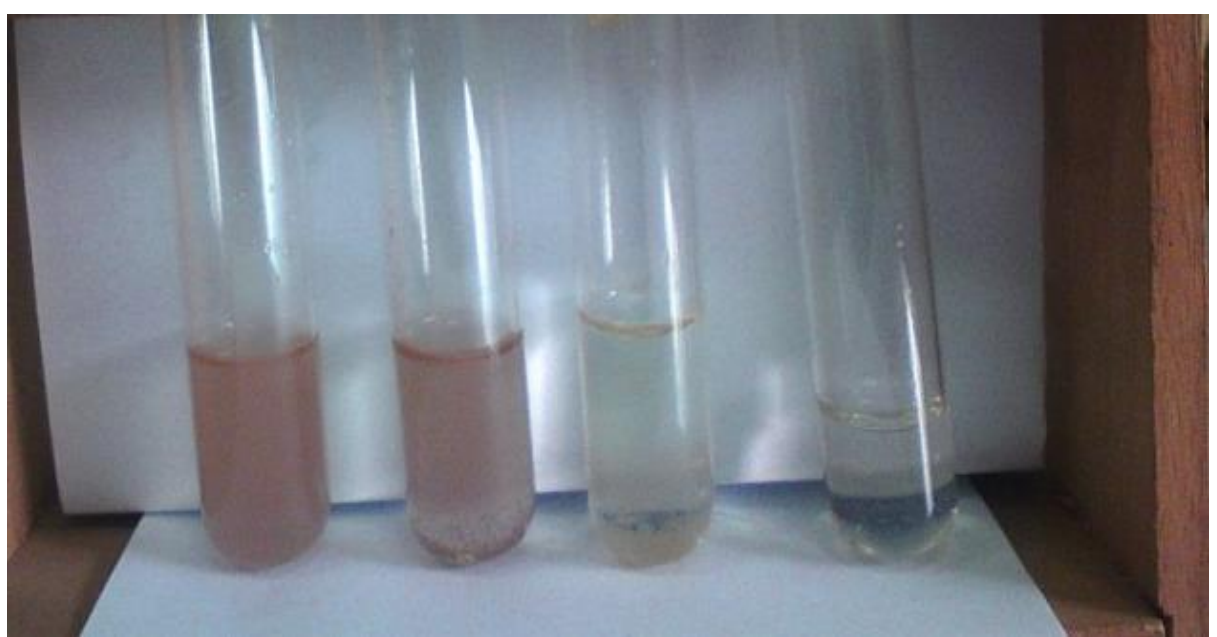

Figure 2. Color changes obtained after 15 min of mixing CFE's of (from left to right) St. thermophilus, L. acidophilus, E. coli, and B. subtilis with $10.3 \mathrm{M} \mathrm{HAuC}_{14}$ solutions in $1: 1(\mathrm{v} / \mathrm{v})$ ratio and at $37^{\circ} \mathrm{C}$.

The addition of wet bacterial cell biomass (CBM) to $10^{-3} \mathrm{M} \mathrm{HAuC}_{14}$ at $37^{\circ} \mathrm{C}$ and $\mathrm{pH} 7$ also resulted in AuNPs formation. Figure 3 shows the color changes accompanying CBM action on $10^{-3} \mathrm{M} \mathrm{HAuC14}$ solutions.

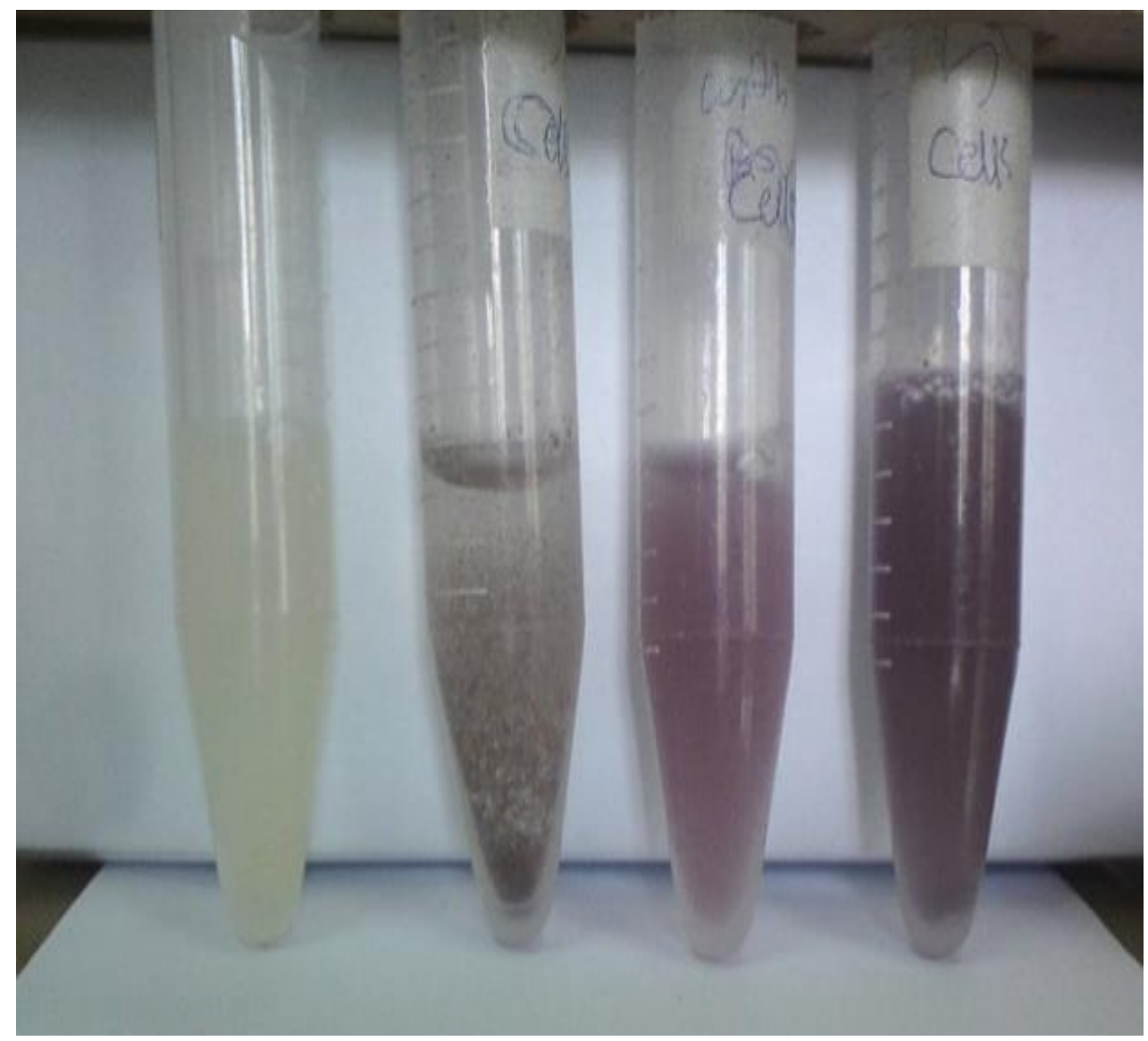

Figure 3. Color changes obtained after 15 min of suspension of wet CBM of L. acidophilus, E. coli, B. subtilis and St. thermophilus (from left to right) with $10^{-3} \mathrm{M} \mathrm{HAuCl} 4$ solution at $37^{\circ} \mathrm{C}$. 
Figure 4 (a-d) shows the UV-vis. spectra of AuNPs formed CFE's of E. coli, St. thermophilus, L. acidophilus and B. subtilis showing an absorption band at $520 \mathrm{~nm}$. The band at $520 \mathrm{~nm}$ is characteristic of un-aggregated AuNPs that found stabilized during the formation period $(15 \mathrm{~min})$ at $37^{\circ} \mathrm{C}$. A comparative work was held out for biosynthesis of AuNPs using bacterial CFE's and CBM. The UV-vis Spectra of the CFE's and CBM samples measured. Figure 5 (a-c) shows the UV- vis. Spectra of incubation products of CBM of B. subtilis, E. coli, and St. thermophilus with $10^{3} \mathrm{M} \mathrm{HAuC}_{14}$ solutions, after $15 \mathrm{~min}$, and at $37^{\circ} \mathrm{C}$. The spectra show products characteristic to AuNPs.
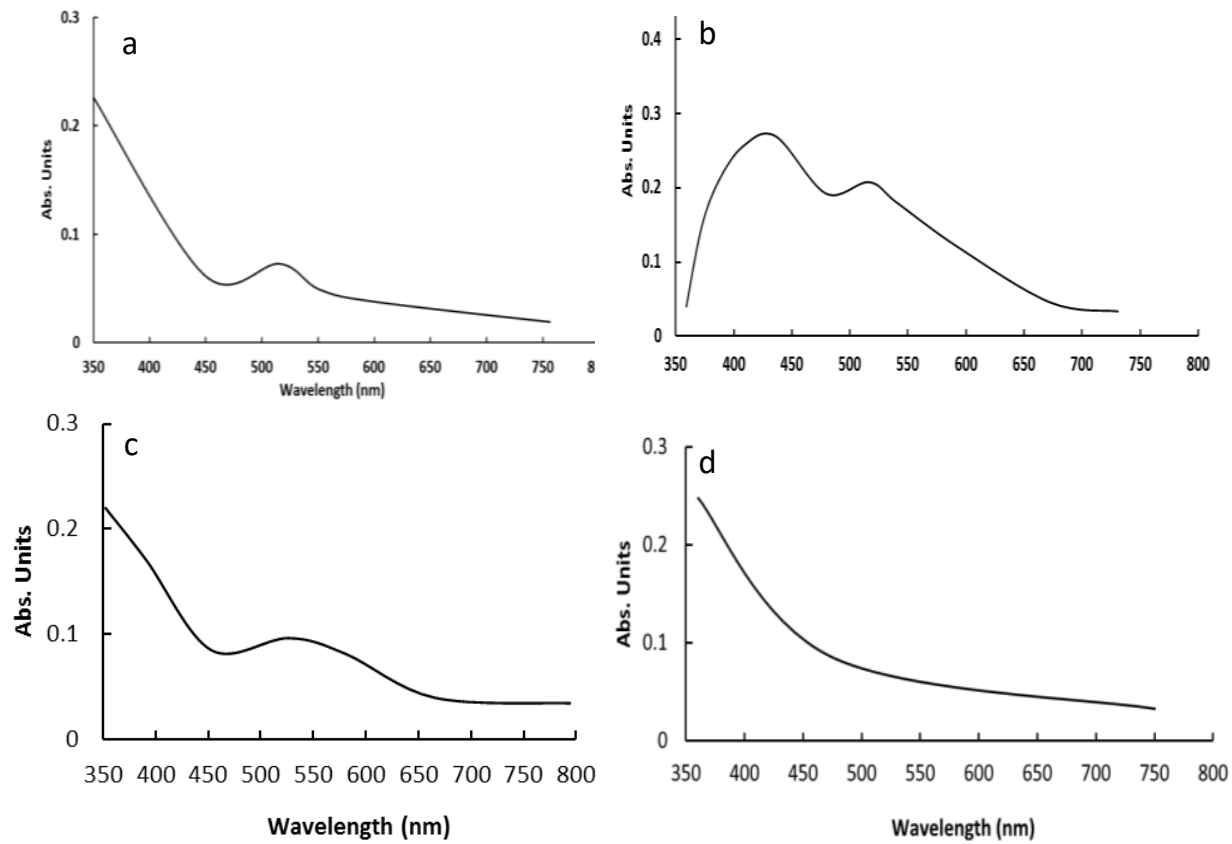

Figure 4. UV-vis. the spectrum of incubation products of CFE's of E. coli (a), St. thermophilus (b), L. acidophilus (c) and B. subtilis (d) with $10^{-3} \mathrm{M} \mathrm{HAuC}_{14}$ solution in $1: 1\left(\mathrm{v} / \mathrm{v}\right.$ ) ratio for $15 \mathrm{~min}$ and at $37^{\circ} \mathrm{C}$.
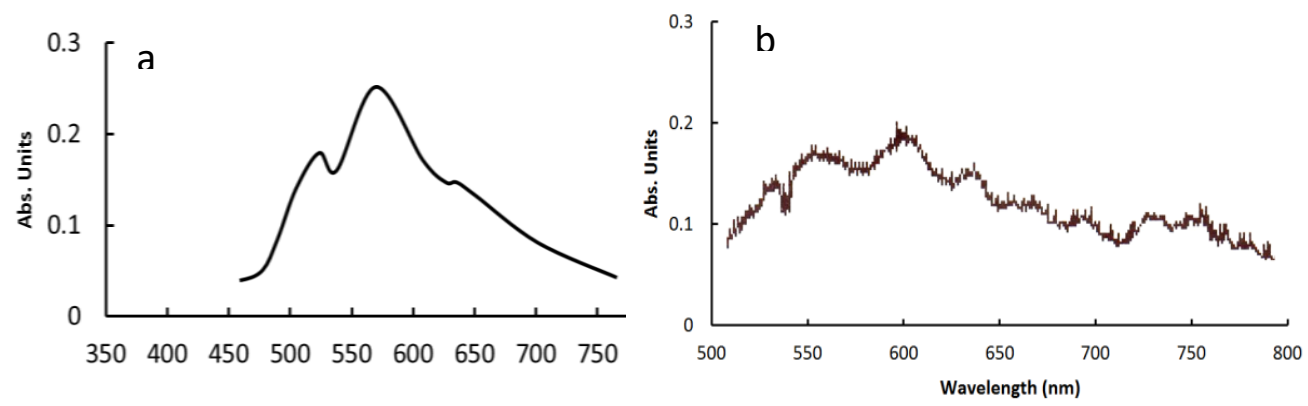

Wavelength $(\mathrm{nm})$

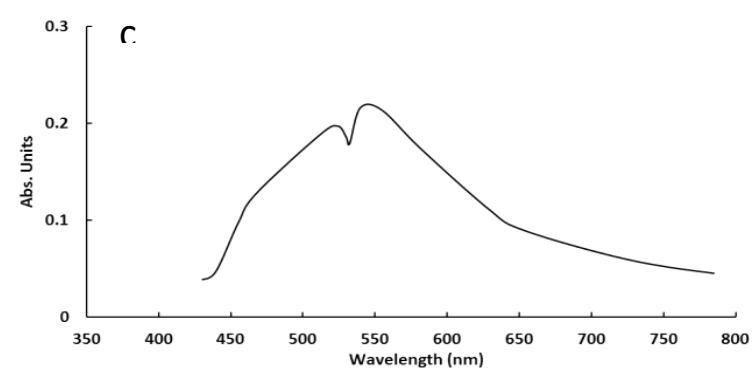

Figure 5. UV-vis. The spectrum of incubation products of CBM of B. subtilis (a), E. coli (b) and St. thermophilus (c) with $10.3 \mathrm{M} \mathrm{HAuC}_{14}$ solution for $15 \mathrm{~min}$ and at $37^{\circ} \mathrm{C}$. 
The nanoparticles formed by the test bacteria imaged using TEM. The images of the AuNPs particles of nanoscale dimensions were corresponding to the round shape (Figure 6).

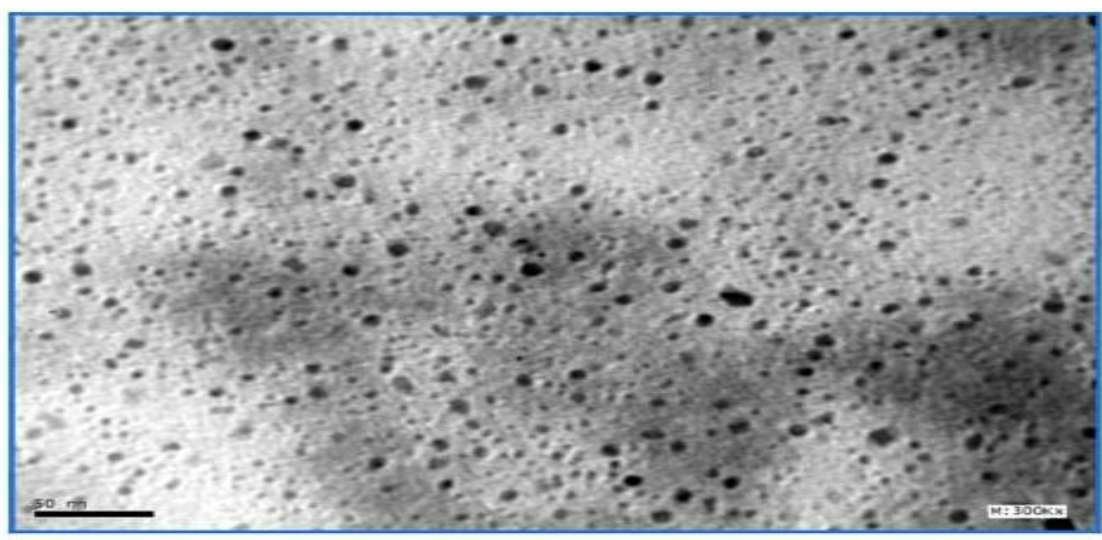

Figure 6. TEM micrograph of Au NPs.

X-ray powder diffraction patterns of producing AuNPs shown in Figure 7 that shows diffraction peaks characteristic of AuNPs. The XRD patterns show four main peaks in the range of $2 \theta$ values from $20^{\circ}$ to $80^{\circ}$ at $2 \theta$ values of $39^{\circ}, 46.5^{\circ}, 64.7^{\circ}$, and $77.6^{\circ}$, corresponding to (111), (20 A gold nanoparticle solution of absorbance: $\mathrm{A}=2.5$ absorbance units used as a stock solution. 0), (220), (311) planes, respectively, for face-centered cubic (fcc) gold nanoparticles. The absorption spectrum of this solution exhibits an absorption most at $520 \mathrm{~nm}$, which consistent with reported values. The positions of the $520 \mathrm{~nm}$ peak remained nearly unchanged, as indicated in Figure 5. The color change from crimson to blue for the control experiment (right) and experiment using target oligonucleotide (left) is pictured in Figure 8. The change in color is due to the formation of large oligonucleotide-binding three- dimensional assemblies of AuNPs and change in particle surface plasmon resonance.

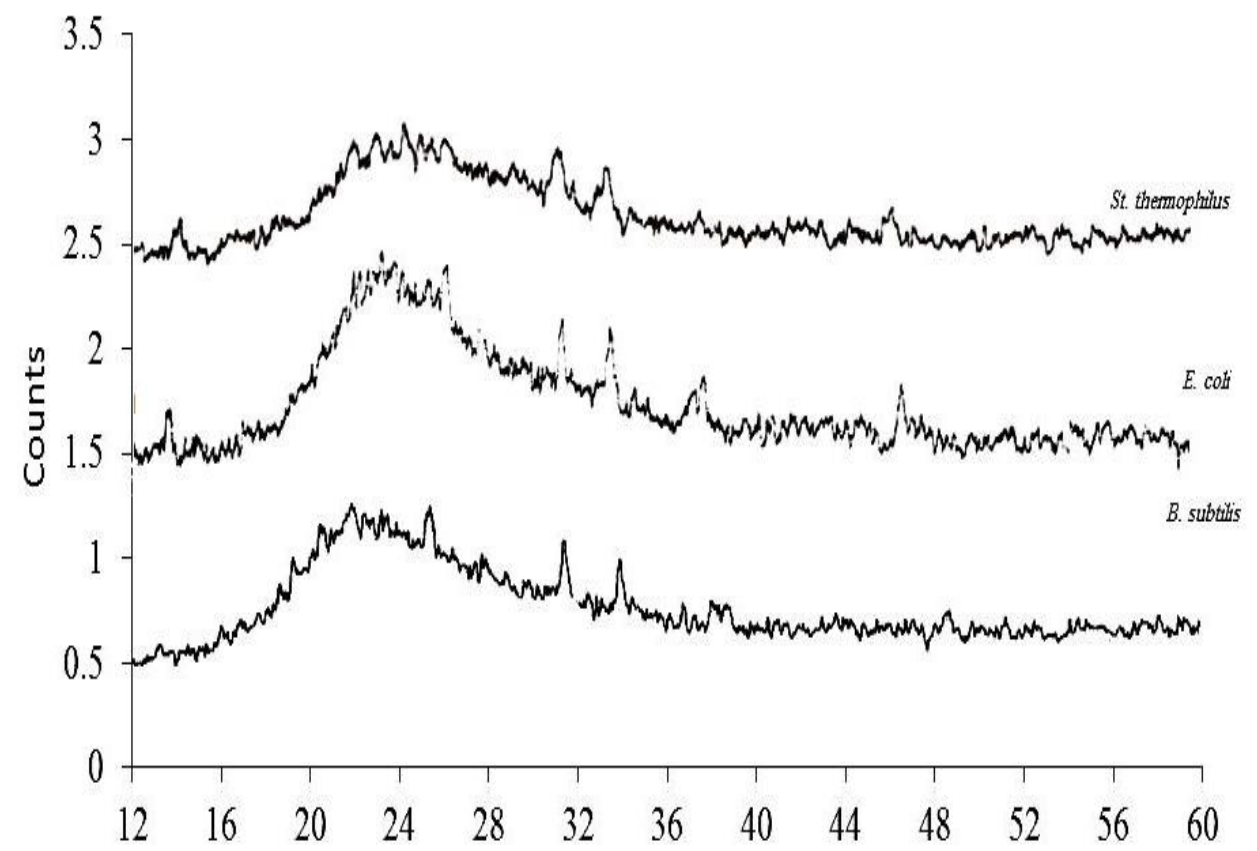

$2 \theta$ degree

Figure 7. X-ray powder diffraction patterns of AuNPs synthesized by B. subtilis, E. coli, and St. thermophilus. 


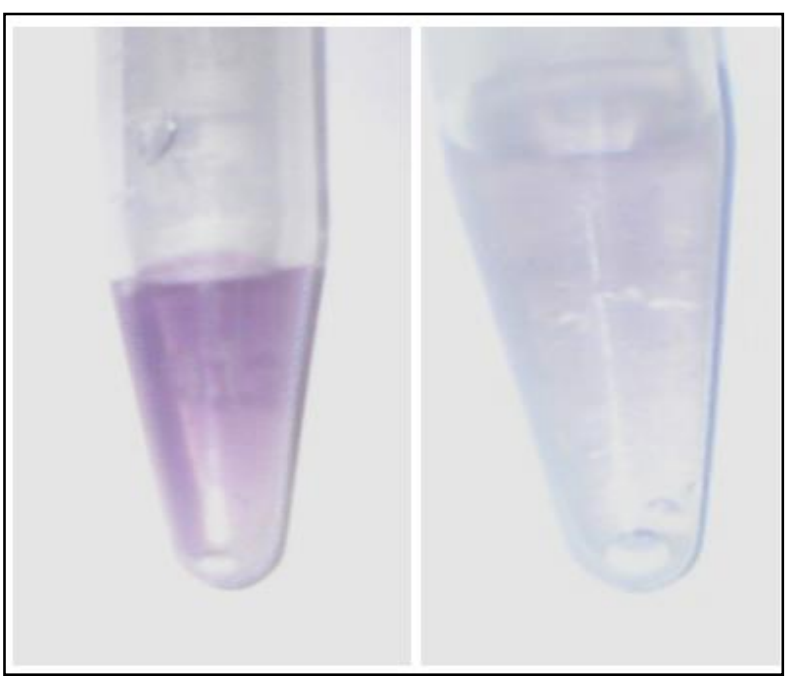

Figure 8. Change in color for the control experiment (right) and experiment using target oligonucleotide (left).

The UV-Vis spectra of unlinked AuNPs probes and of assembled nanoparticle probes after treatment with the 20-base oligonucleotide, following their freezing at the temperature of the dry ice and thawing at room temperature, are shown in Figure 9. Upon mixing unlinked AuNPs solutions in a buffer solution, no change in spectral absorption pattern occurred, and this chosen as a control experiment (Figure 9). Upon mixing the loaded gold nanoparticles solutions in the mien of the target oligonucleotide: 5'CCAAGAGGGACGGGAACCTC-3', a change in absorption spectral pattern occurred, producing a broader absorption band as a result of AuNPs aggregation as shown in Figure 8. This accompanied by a color change from crimson to blue, as pictured in Figure 8.

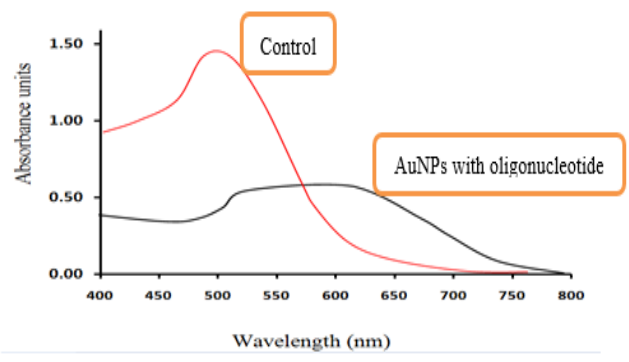

Figure 9. The change in absorption spectra.

The size, shape, and output of the biosynthesized nanoparticles in vivo much depend on physiological limits and remarkably affected by growth conditions. In this study, the optimum concentration of $\mathrm{HAuC}_{14}$ for gold nanoparticles (AuNPs ) biosynthesis using bacterial cell-free extracts (CFE's) and cell biomass (CBM) of Escherichia coli A TCC 8739, Bacillus subtilis ATCC 6633, Streptococcus thermophilus ESH1 and Lactobacillus acidophilus DSMZ is around $10^{-3} \mathrm{M}$. Higher concentrations of $\mathrm{HAuC}_{14}$ may cause precipitation of enzyme due to salting-out. However, St. thermophilus shows production at $10^{-2} \mathrm{M}$ of $\mathrm{HAuC}_{14}$, but a fast aggregation of gold particles observed. The biosynthesis efficiency of AuNPs increased with increasing temperature until an optimum temperature in the range $35-37^{\circ} \mathrm{C}$. A decrease in biosynthesis occurs at ca. $45^{\circ} \mathrm{C}$ due to enzyme deactivation. Accordingly, the rapid biosynthesis of stable AuNPs was performed in this investigation using CFE's and CBM of E. coli A TCC 8739, B. subtilis ATCC 6633, St. thermophilus ESH1 and L acidophilus DSMZ is shown at 37 ${ }^{\circ} \mathrm{C}$ and $\mathrm{pH} \mathrm{7,} \mathrm{and} \mathrm{within} \mathrm{fifteen} \mathrm{minutes.} \mathrm{These} \mathrm{results} \mathrm{confirmed} \mathrm{by} \mathrm{the} \mathrm{outcomes} \mathrm{obtained}$ 
$[15,25]$, who demonstrated that gold particles of nanoscale dimensions readily precipitated within bacterial cells by incubation of the cells with $\mathrm{Au}^{3+}$ ions. The extracellular formation of gold nanoparticles offered a big advantage over an intracellular process of synthesis from the application point of view, as supported by the effects obtained from the CFE's of nonpathogenic bacteria $[14,15]$.

The outcomes of this study indicated color changes of $\mathrm{HAuC}_{14}$ mixed with CFE's and CBM from yellow to pink. This confirmed by the fact that the AuNPs characterized by pink coloration due to excitation of Surface Plasmon Resonance (SPR), which brings up to the collective oscillation of the free electrons along the surface of AuNPs when they are hit by light [49,50,51]. Diffraction peaks characteristic of AuNPs obtained in this field using the selected test bacteria that standardized to those covered [52,53]. The XRD patterns showed four main points, similar to those received by Sun et al. [54]. The absorption spectrum of AuNPs obtained from the tested bacteria showed an absorption maximum at $520 \mathrm{~nm}$, which is coherent with the reported values [55]. The absorption of gold ions played a significant function in shaping and stabilizing the frame of gold nanocrystals [22,36]. The reduction of the metal ions, rapid synthesis, and the stabilization of the AuNPs biosynthesized in this study believed to die off by enzymes, acids, and hydrolyzable compounds present in the extract, or secreted by the bacteria cells. In this connection, some investigators suggested that the main groups of the enzyme secreted by biomass may play a significant role in reducing the $\mathrm{Au}^{3+}$ ions include amino, sulfhydryl, and carboxylic groups and the $\mathrm{Au}^{3+}$ ions could bind to biomass through these working groups [56-58]. Previous studies [14,59] have indicated that NADH and NADHdependent enzymes are important factors in the biosynthesis of metal nanoparticles. The secretion of the cofactors NADH and NAD+- dependent enzymes responsible for reducing $\mathrm{Au}^{3+}$ to $\mathrm{Au}^{0}$ and the next formation of AuNPs. The reduction appears initiated by electron transport from the NADH by NADH-dependent reductase as an electron carrier [22,31], then the gold ions obtain electrons and are reduced to $\mathrm{Au}^{0}$ [60]. Certain capping proteins secreted by the bacteria could be responsible for the establishment and stability of AuNPs [26].

The AuNPs-based colorimetric method used to detect unamplified HCV RNA extracted from clinical specimens directly. The simplicity and sensitivity of AuNP-based nucleic acid colorimetric assays have encouraged the development of a cheap assay for HCV virus detection [44]. The assay used to directly detect unamplified HCV RNA extracted from the serum of clinical samples using unmodified AuNPs. A colorimetric assay using unmodified citratecoated AuNPs (negatively charged) based on the fact that single-stranded DNA (ssDNA) adsorbs on citrate-coated AuNPs. This adsorption increases the negative direction of the AuNPs, leading to increased repulsion between the molecules, thus preventing aggregation. The adsorption of ssDNA on AuNPs is because of the conclusion that ssDNA is capable of uncoiling and exposing its nitrogenous bases at a low cost. The attractive electrostatic forces between the bases and the AuNPs enable the adsorption of the ssDNA. Hepatitis C Virus-NS4 emerged as the main pathogen in the liver diseases in Egypt. Many clinical diagnostic applications need simpler and inexpensive assays that can be solved in a viewing mode. In the fields of diagnostics, the application of AuNPs tested in this study for viral detection of HCVNS4. A target oligonucleotide of HCV genotype 4 possessing a high CG ratio of the base sequence: 5'-CCA AGA GGG A CGGGA ACC TC-3' chosen for viral detection using gold nanoparticles aggregation. Two complementary probes synthesized and linked to hexane thiols as follows: Probe 1: 3'-GGT TCT CCC T $\left(\mathrm{CH}_{2}\right)_{6}$-HS 5', Probe2: 3'-GCC CTT GGA G $\left(\mathrm{CH}_{2}\right)_{6}$ -HS 5'. AuNPs of $\approx 13$ diameters prepared then modified with 5'-hexanethiol probes that 
aligned in a head-to-tail fashion to the complementary 20-base target oligonucleotide. Upon freezing and thawing the solution, the color changed from red to pinkish/purple. This color change attributed to form large DNA-linked three- dimensional assemblies of AuNPs, which led to broadening and redshift in the particle Surface Plasmon Resonance (SPR) [46]. When a similar mixture, a mixture containing $150 \mu$ of gold nanoparticle with each probe 1and 2 and $6 \mu \mathrm{l}$ of the target oligonucleotide in a hybridization buffer allowed to cool down to $-100^{\circ} \mathrm{C}$ and then allowed to warm to room temperature, the solution color changed from red to pink. This change results in modest broadening and redshift in the particle SPR. This is due to the effect of cooling on the extent of the maturation of high local concentration of oligonucleotide target and AuNPs within pockets in the glass structure. A control experiment performed by mixing $150 \mu \mathrm{l}$ of gold nanoparticle with each probe ( 1 and 2 ) in the absence of linking oligonucleotide 3. Freezing at the temperature of dry ice and thawing to room temperature did not result in a calorimetric change or any alteration in the particle SPR. So, if the color stayed on red, the virus is not present in the sample. If it switched to blue, the sample is positive for HCV. In $\mathrm{HCV}$ positive specimens, the vividness of the solution changed from crimson to blue within 1 minute.

\section{Conclusions}

Rapid extracellular biosynthesis of stable AuNPs recovered by reduction of $\mathrm{Au}^{3+}$ ions with CFE's and CBM of E. coli A TCC 8739, B. subtilis ATCC 6633, St. thermophilus ESH1 and L. acidophilus DSMZ in 15 min at $37^{\circ} \mathrm{C}$, and $\mathrm{pH}$ 7. The color of the mixture of $\mathrm{HAuC}_{14}$ CFE's and CBM changed from pale yellow to reddish. The formed nanoparticles have UVvisible spectroscopy of the absorption band at $520 \mathrm{~nm}$, XRD, and TEM characteristics of AuNPs. Assembly of AuNPs with DNA of HCV-NS4 that resulted in the rapid change of the color from red to blue makes the test reliable to detect HCV infection. The developed assay allows the rapid detection of unamplified HCV-NS4 ribonucleic acid extracted from samples containing the virus. It should provide AuNPs utilized in virus detection.

\section{Funding}

This research received no external funding.

\section{Acknowledgments}

Thanks are extended to Prof. M. El-Saadany, Alexandria University, for help and support in this study.

\section{Conflicts of Interest}

The authors do not declare any conflict of interest.

\section{References}

1. Chandra, P.; Singh, J.; Singh, A.; Srivastava, A.; Goyal, R.N.; Shim, Y. Gold nanoparticles and nanocomposites in clinical diagnostics using electrochemical methods. J. Nanopart. 2003, 2013, 1-13, https://doi.org/10.1155/2013/535901.

2. Schröfel, A.; Kratošová, G. Biosynthesis of metallic nanoparticles and their applications. In: Prokop A. editor. Intracellular delivery: Fundamentals and applications. Ed. Netherlands, Springer, 2011; pp. 373409. 
3. Sherry, D.A.; Prakash, P.; Thamaraiselvi, K. Nanobioremediation Technologies for Sustainable Environment. In: Bioremediation and Sustainable Technologies for Cleaner Environment. Environmental Science and Engineering. Ed. Prashanthi M.; Sundaram R.; Jeyaseelan A.; Kaliannan T. Springer, Cham 2017, pp. 13-33, https://doi.org/10.1007/978-3-319-48439-6_2

4. El Behiry A. Diagnostic aspects and novel approach for treatment of antibiotic-resistant bacteria isolated from diarrheal calves using silver, gold and copper nanoparticles. J. Bacteriol. Parasitol. 2014, 5, https://doi.org/10.4172/2155-9597.1000195.

5. Shah, M.; Badwaik, V.D.; Dakshinamurthy R. Biological applications of gold nanoparticles. J. Nanosci. Nanotechnol. 2014, 14, 344-362, https://doi.org/10.1166/jnn.2014.8900.

6. Shipra, P.; Madhuree, K.; Satyendra Pratap, S.; Arpita, B.; Shashank, M.; Puneet Singh, C.; Aradhana, M. Bioremediation via nanoparticles: An innovative microbial approach. In: Handbook of research on uncovering new methods for ecosystem management through bioremediation. Ed. Singh S.; Srivastava, K.H.P.A: IGI Global, 2015, pp. 491-515, https://doi.org/10.4018/978-1-4666-8682-3.ch019.

7. Afifi, H.A.M.; Geweely, N.S.; Galal, H.S.; Abdelrahim, S.A.; Al-Qudsi, F.M.S. Antimicrobial Activity of Gold Nanoparticles (AuNPs) on Deterioration of Archeological Gilded Painted Cartonnage, Late Period, Saqqara, Egypt. Geomicrobiology Journal 2016, 33, 1-8, https://doi.org/10.1080/01490451.2015.1062064.

8. El-Shanshoury, A.R.; Darwesh, O.M.; Sabae, Sh. Z.: Awadallah, O. A.; Hassan, S. H.. Bio-manufacturing of selenium nanoparticles by Bacillus subtilis isolated from Qarun Lake and evaluation their activity for water remediation. Biointerf. Res. Appl. Chem. 2020, 10, 5834-5842.

9. Ramezani, N.; Ehsanfar, Z.; Shamsa, F.; Amin, G.; Shahverdi, H.; Shamsaie, A.; Bazaz, R.; Shahverdi, A.R. Screening of Medicinal Plant Methanol Extracts for the Synthesis of Gold Nanoparticles by Their Reducing Potential. Zeitschrift fur Naturforschung - Section B Journal of Chemical Sciences 2008, 63, 903-908, https://doi.org/10.1515/znb-2008-0715.

10. Krumov, N.; Perner, I.N.; Oder, S.; Gotcheva, V.; Angelov, A.; Posten, C. Production of inorganic nanoparticles by microorganisms. Chem. Eng. Technol. 2009, 32, 1026-1035, https://doi.org/10.1002/ceat.200900046.

11. Rai, M.; Duran, N. Metal nanoparticles in microbiology. $1^{\text {st }}$ ed. Heidelberg, Berlin: Springer, 2011.

12. Ingale, A.; Chaudhari, A.N. Biogenic synthesis of nanoparticles and potential applications: An eco-friendly approach. J. Nanomed. Nanotechol. 2013, 4, 165-171, https://doi.org/10.4172/2157-7439.1000165.

13. Manimaran, M.; Kannabiran K. Actinomycetes-mediated biogenic synthesis of metal and metal oxide nanoparticles: progress and challenges. Lett. Appl. Microbiol. 2017, 64, 401-408, https://doi.org/10.1111/lam.12730.

14. Lee, K.X.; Shameli, K.; Yew, Y.P.; Teow, S.Y.; Jahangirian, H.; Rafiee-Moghaddam, R.; Webster, T.J. Recent developments in the facile bio-Synthesis of gold nanoparticles (AuNPs) and their biomedical applications. Int. J. Nanomed. 2020, 15, 275-280, https://doi.org/10.2147/IJN.S233789.

15. Beveridge, T.J.; Murray, R.G.E. Sites of metal deposition in the cell wall of Bacillus subtilis. J. Bacteriol. 1980, 41, 876-887.

16. El-Shanshoury, A.R.; El-Silk, S.E.; Ebeid, M.E. Extracellular biosynthesis of silver nanoparticles using Escherichia coli ATCC 8739, Bacillus subtilus ATCC 6633 and Streptococcus thermophilus ESh1 and their antimicrobial activities. ISRN Nanotechnol. 2011, 2011, 1-7, https://doi.org/10.5402/2011/385480.

17. El-Shanshoury, A.R.; El-Silk, S.E.; Ebeid, M.E. Rapid biosynthesis of cadmium sulfide (CdS) nanoparticles using culture supernatants of Escherichia coli ATCC 8739, Bacillus subtilis ATCC 6633 and Lactobacillus acidophilus DSMZ 20079T. Afric. J. Biotechnol. 2012a, 11, 7957-7965.

18. El-Shanshoury, A.R.; El-Silk, S.E.; Ebeid, Z.M.; Ateya, P.S. Synthesis of lead nanoparticles by Enterobacter sp. and avirulent Bacillus anthracis PS2010. Ann. Microbiol. 2012b, 62, 1803-1810, https://doi.org/10.1007/s13213-012-0438-3.

19. Abo-Amer, A.E.; El-Shanshoury, A.R.; Alzahrani, O.M. Isolation and molecular characterization of heavy metal-resistant Alcaligenes faecalis from sewage wastewater and synthesis of silver nanoparticles. Geomicrobiol. J. 2015, 32, 836-845, https://doi.org/10.1080/01490451.2015.1010754.

20. Beveridge, T.J.; Hughes, M.N.; Lee, H.; Leung, K.T.; Poole, R.K.; Savvaidis, I.; Silver, S.; Trevors, J.T. Metal-microbe interactions: Contemporary approaches. Adv. Microbial. Physiol. 1997, 38, 177-243, https://doi.org/10.1016/S0065-2911(08)60158-7.

21. He, S.; Guo, Z.; Zhang, Y.; Zhang, S.; Wang, J.; GU, N. Biosynthesis of gold nanoparticles using the bacteria Rhodopseudomonas capsulate. Mat. Lett. https://doi.org/10.1016/j.matlet.2007.01.018.

22. He, S.; Zhang, Y.; Guo, Z.; GU, N. Biological synthesis of gold nanowires using an extract of Rhodopseudomonas capsulate. Biotechnol. Prog. 2008, 24, 476-480, https://doi.org/10.1021/bp0703174.

23. Lilia, M.; Fernando, L.M.; Merca, F.E.; Paterno, E.S. Biogenic synthesis of gold nanoparticles by plantgrowth-promoting bacteria isolated from Philippine soils. The Philippine Agricul. Sci. 2013, 96, 129-136.

24. Reddy, A.S.; Chen, C.Y.; Chen, C.C.; Jean, J.S.; Chen, H.R.; Tseng, M.J.; Fan, C.W.; Wang, J.C. Biological synthesis of gold and silver nanoparticles mediated by the bacteria Bacillus subtilis. J. Nanosci. Nanotechnol. 2010, 10, 6567-6574, https://doi.org/10.1166/jnn.2010.2519. 
25. Otari, S.V.; Patil, R.M.; Nadaf, N.H.; Ghosh, S.J.; Pawar, S.H. Green synthesis of silver nanoparticles by microorganism using organic pollutant: its antimicrobial and catalytic application. Environ. Sci. Pollut. Res. 2014, 21, 1503-1513, https://doi.org/10.1007/s11356-013-1764-0.

26. Husseiny, M.I.; Abd El-Aziz, M.; Badr, Y.; Mahmoud, M.A. Biosynthesis of gold nanoparticles using Pseudomonas aeruginosa. Spectroch Acta Part A 2007, 67, 1003-1006, https://doi.org/10.1016/j.saa.2006.09.028.

27. Fayaz, A.M.; Girilal, M.; Rahman, M.; Venkatesan, R.; Kalaichelvan, P.T. Biosynthesis of silver and gold nanoparticles using thermophilic bacterium Geobacillus stearothermophilus. Process Biochem. 2011, 46, 1958-1962, https://doi.org/10.1016/j.procbio.2011.07.003.

28. Radhika Rajasree, S.R.; Suman, T.Y. Extracellular biosynthesis of gold nanoparticles using a gram negative bacterium Pseudomonas fluorescens. Asian Pacific J. Trop. Dis. 2012, 2, S795-S799, https://doi.org/10.1016/S2222-1808(12)60267-9.

29. Malarkodi, C.; Rajeshkumar, S.; Vanaja, M.; Paulkumar, K.; Gnanajobitha, G.; Annadurai, G. Eco-friendly synthesis and characterization of gold nanoparticles using Klebsiella pneumonia. J. Nanost. Chem. 2013, 3, 30, https://doi.org/10.1186/2193-8865-3-30.

30. Rosi, N.L.; Mirkin, C.A. Nanostructures in biodiagnostics. Chem. Rev. 2005, 105, 1547-1562, https://doi.org/10.1021/cr030067f.

31. Kumar, S.A.; Ansary, A.A.; Abroad, A.; Khan, M.I. Extracellular biosynthesis of CdS quantum dots by the fungus. Fusarium oxysporum. J. Biomed. Nanotechnol. 2008, 3, 190-194, https://doi.org/10.1166/jbn.2007.027.

32. Jain, K.K. Nanotechnology in clinical laboratory diagnostics. Clin. Chim. Acta 2009, 358, 37-54, https://doi.org/10.1016/j.ccen.2005.03.014.

33. Schultz, S.; Smith, D.R.; Mock, J.J.; Schultz, D.A. Single-target molecule detection with nonbleaching multicolor optical immunolabels. Proc. Natl. Acad. Sci. USA 2000, 97, 996-1001, https://doi.org/10.1073/pnas.97.3.996.

34. Storhoff, J.J.; Elghanian, R.; Mucic, R.C.; Mirkin, C.A.; Letsinger, R.L. One-pot colorimetric differentiation of polynucleotides with single base imperfections using gold nanoparticle probes. J. Am. Chem. Soc. 1998, 120, 1959-1964, https://doi.org/10.1021/ja972332i.

35. Whaley, S.R.; English, D.S.; Hu, E.L.; Barbara, P.F.; Belcher, A.M. Selection of peptides with semiconductor binding specificity for directed nanocrystal assembly. Nature 2000, 405, 665-668, https://doi.org/10.1038/35015043.

36. Delapierre, T.M.; Majimel, J.; Mornet, S.; Duguet, E.; Ravaine, S. Synthesis of nonspherical gold nanoparticles. Gold. Bull. 2008, 41, 195-207, https://doi.org/10.1007/BF03216597.

37. Yeonee, S.; Amanda, E.; Thomas, T.P. Gold nanoparticles: enhanced optical trapping and sensitivity coupled with significant heating. Optics Lett. 2006, 31, 2429-2431, https://doi.org/10.1364/ol.31.002429.

38. Nath, S.: Kaittanis, C.; Tinkham, A.; Perez, J.M. Dextran-coated gold nanoparticles for the assessment of antimicrobial susceptibility. Anal. Chem. 2008, 80, 1033-1038, https://doi.org/10.1021/ac701969u.

39. Mirkin, C.A.; Letsinger, R.L.; Mucic, R.C.; Storhoff, J.J. A DNA-based method for rationally assembling nanoparticles into macroscopic materials. Nature 1996, 382, 607- 609, https://doi.org/10.1038/382607a0.

40. Elghanian, R.; Storhoff, J.J.; Mucic, R.C.; Letsinger, R.L.; Mirkin, C.A. Selective colorimetric detection of polynucleotides based on the distance-dependent optical properties of gold nanoparticles. Science 1997, 277, 1078-1081, https://doi.org/10.1126/science.277.5329.1078.

41. Kaittanis, C.; Santra, S.; Perez, J.M. Emerging nanotechnology-based strategies for the identification of microbial pathogenesis. Adv. Drug Deliv. Rev. 2010, 62, 408-423, https://doi.org/10.1016/j.addr.2009.11.013.

42. Yeh, Y.C.; Creran, B.; Rotello, V.M. Gold nanoparticles: preparation, properties, and applications in bionanotechnology. Nanoscale 2012, 4, 1871-1880, https://doi.org/10.1039/C1NR11188D.

43. Timm, J.; Neukamm, M.; Kuntzen, T.; Kim, A.Y.; Chung, R.T.; Brander, C.; Lauer, G.M.; Walker, B.D.; Allen, T.M. Characterization of full-length hepatitis C virus genotype 4 sequences. J. Viral Hepat. 2007, 14, 330-337, https://doi.org/10.1111/j.1365-2893.2006.00792.x.

44. Shawky, S.M.; Bald, D.; Azzazy, H.M. Direct detection of unamplified hepatitis C virus RNA using unmodified gold nanoparticles. Clin. Biochem. 2010, 43, 1163-1168.

45. Attallah, A.M.; Omran, M.M.; Nasif, W.A.; Ghaly, M.F.; El-Shanshoury, A.E.-R.R.; Abdalla, M.S.; Sharada, H.M.; Farid, K.; El-Shony, W.; Moussa, E.-S.M.; El-Domany, E.B.; Nour, E.; Eldosoky, I. Diagnostic Performances of Hepatitis C Virus-NS4 Antigen in Patients with Different Liver Pathologies. Archives of Medical Research 2012, 43, 555-562, doi:https://doi.org/10.1016/j.arcmed.2012.09.010.

46. Draz, M.S.; Shafiee, H. Applications of gold nanoparticles in virus detection. Theranostics 2018, 8, 19852017, https://dx.doi.org/10.7150\%2Fthno.23856.

47. Luria, S.E.; Burrous, J.W. Hybridization between Escherichia coli and Shigella. J. Bacteriol. 1955, 74, 461476.

48. Lee, S.Y.; Vedamuthu, E.R.; Washam, C.J.; Reinbold, G.W. An agar medium for the differential enumeration of yogurt starter bacteria. J. Milk Food Technol. 1974, 37. 
49. Henglein, A. Physicochemical properties of small metal particles in solution: microelectrode reactions, chemisorption, composite metal particles, and the atom-to-metal transition. J. Phys. Chem. B 1993, 97, 5457-5471, https://doi.org/10.1021/j100123a004.

50. Lu, H.W.; Liu, S.H.; Wang, X.L.X.; Qian, F.; Yin, J.; Jhu, J.K. Silver nanocrystals by hyperbranched polyurethane-assisted photochemical reduction of Ag+. Mat. Chem. Phys. 2003, 81, 104-107, https://doi.org/10.1016/S0254-0584(03)00147-0.

51. Sastry, M.; Ahmad, A.; Islam, N.; Kumar, R. Biosynthesis of metal nanoparticles using fungi and actinomycete. Curr. Sci. 2003, 85, 162-170.

52. Guinier, A. X-ray Diffraction in crystals, imperfect crystals, and amorphous bodies. USA, Courier Dover Publications 1994.

53. Ankamwar, B. Biosynthesis of gold nanoparticles (Green gold) using leaf extract of Terminalia catappa. E.J. Chem. 2008, 7, 1334-1339, https://doi.org/10.1155/2010/745120.

54. Sun, K.; Qiu, J.; Liu, J.; Miao, Y. Preparation and characterization of gold nanoparticles using ascorbic acid as reducing agent in reverse micelles. J. Mater. Sci. 2009, 44, 754-758, https://doi.org/10.1007/s10853-0083162-4.

55. Reynolds, R.A.; Mirkin, C.A.; Letsinger, R.L. A gold nanoparticle/latex microsphere-based colorimetric oligonucleotide detection method. J. Am. Chem. Soc. 2000, 122, 3795-3797, https://doi.org/10.1351/pac200072010229.

56. Mukherjee, P.; Mandal, D.; Senapati, SRamani, R.; Ajayakumar, P.; Sastry, M.; Kumar, R. Bioreduction of AuCl4- Ions by the Fungus, Verticillium sp. and Surface Trapping of the Gold Nanoparticles Formed. Angewandte Chemie International Edition 2001, 40, 3585-3588.

57. Ahmad, A.; Senapati, S.; Khan, M.I.; Kumar, R.; Ramani, R.; Srinivas, V.; Sastry, M. Intracellular synthesis of gold nanoparticles by a novel alkalotolerant actinomycetes Rhodococcus species. Nanotechnol. 2003, 14, 824-828, https://doi.org/10.1088/0957-4484/14/7/323.

58. Armendariz, V.; Herrera, I.; peralta-videa, J.R.; Jose-yacaman, M.; Troiani, H.; Santiago, P.; GardeaTorresdey, J.L. Size-controlled gold nanoparticle formation by Avena sativa biomass: use of plants in nanobiotechnology. J. Nanopart. Res. 2004, 6, 377-382, https://doi.org/10.1007/s11051-004-0741-4.

59. Senapati, S.; Ahmed, A.; Khan, M.I.; Kumar, R.; Sastry, M. Extracellular biosynthesis of bimetallic Au-Ag alloy nanoparticles. Small1 2005, 5, 517-520, https://doi.org/10.1002/smll.200400053.

60. Zhang, Y.; Peng, H.; Huang, W.; Zhou,Y.; Yan, D. Facile preparation and characterization of highly antimicrobial colloid $\mathrm{Ag}$ or $\mathrm{Au}$ nanoparticles. J. Colloid. Interf. Sci. 2008, 325, 371-376, https://doi.org/10.1016/j.jcis.2008.05.063. 